\title{
Reasons for the Survival of Tropical Forest Fragments in Xishuangbanna, Southwest China
}

\author{
Jia-Qi Zhang ${ }^{1,2}$, Christos Mammides ${ }^{3}(1)$ and Richard T. Corlett ${ }^{1,4, *(1)}$ \\ 1 Center for Integrative Conservation, Xishuangbanna Tropical Botanical Garden, \\ Chinese Academy of Sciences, Menglun, Yunnan 666303, China; zhangjiaqi@xtbg.ac.cn \\ 2 University of Chinese Academy of Sciences, Beijing 100049, China \\ 3 Guangxi Key Laboratory of Forest Ecology and Conservation, College of Forestry, Guangxi University, \\ Daxuedonglu 100, Nanning 530004, China; cmammides@outlook.com \\ 4 Center of Conservation Biology, Core Botanical Gardens, Chinese Academy of Sciences, Menglun, \\ Yunnan 666303, China \\ * Correspondence: corlett@xtbg.org.cn; Tel.: +86-182-8805-9408
}

Received: 4 January 2020; Accepted: 30 January 2020; Published: 31 January 2020

\begin{abstract}
Research Highlights: The reasons for persistence of forest fragments in human-dominated landscapes have rarely been examined, despite their importance in biodiversity and ecosystem services. We determined these reasons for forest fragments on collective land in Xishuangbanna prefecture, southwest China. Background and Objectives: Reconciling economic development with biodiversity conservation has been a major challenge in China's small tropical land area, where local realities have often been in conflict with national policies. In Xishuangbanna, much of China's most biodiverse forest area has been replaced by cash crops in recent decades, but numerous small forest fragments remain on collective land. Our objective was to find out why these fragments have not been cleared. Methods: We used a combination of semi-structured interviews with 600 households in 69 villages representing nine ethnic groups and information from key informants. Results: Overall, $64 \%$ of individual households retained forest fragments on the land allocated to them, and $93 \%$ of villages retained larger areas managed as a collective forest. Most (71\%) interviewees said that fragments on their own land were on sites of low agricultural value and were retained as fuelwood sources. They were also often (33\%) underplanted with crops and supplied other forest products. All interviewees attributed the retention of collective forests to policy restrictions on clearance, with most $(96 \%)$ mentioning cultural and religious uses and many recognizing environmental benefits. Most were also used as sources of wild edible plants (61\%) and other forest products. Many said these collective forests had shrunk over time, particularly in areas suitable for profitable cultivation. Conclusions: China's new ecological redline policy will protect most larger patches of forest in Xishuangbanna, but the smaller fragments on land allocated to individual households are also of conservation value, particularly in areas with no other forest. Some form of compensation scheme is needed to encourage their continued retention.
\end{abstract}

Keywords: biodiversity; conservation; firewood; land-use change; non-timber forest products; sacred groves; tropical forest

\section{Introduction}

Only 3.6\% of China's huge land area is in the tropics, and less than two-thirds of this is below $700 \mathrm{~m}$ above sea-level, meaning that it is largely frost-free. This area (c. 224,000 $\mathrm{km}^{2}$ ) accounts for most of China's tropical crop production (rubber, bananas, coffee, sugar cane, and tropical fruits) and a disproportionate percentage of China's native biodiversity. Crop production and biodiversity 
conservation are generally incompatible land-uses in tropical forest regions, and a focus on crops over the last 50 years has resulted in large and on-going declines in wild species in the Chinese tropics [1-3]. Reconciling economic development through agriculture with biodiversity conservation through forest protection requires both good national policies and their careful application at regional and local levels.

Land-use policy and planning have had a complex history in China over the last 50 years, and new strategies for achieving policy goals continue to be developed and applied [4,5]. With regards to forestland, since 1981 China has implemented the forest management responsibility system, which involves allocating the use rights of the forestland previously controlled by communes to collectives or individual households. Forests are therefore either state-owned (about 38\% of China's forest area) or collectively owned (62\%), with collectively owned forests increasingly being devolved to individual households. Reforms since the late 1990s extended household rights over these devolved forests, allowing secure long-term use and transfers of use rights, although the collectives have retained official ownership [4]. There were also reductions in taxes and fees related to forests, financial incentives for reforestation, and reforms in the allowable annual cut of timber.

These initial reforms were largely intended to increase timber production. After the disastrous Yangtze River floods of 1998, which were blamed partly on deforestation in the upper Yangtze watershed, the central government introduced new policies to protect forests from clearance and overexploitation, and to encourage reforestation [6]. These policies were implemented through two huge national programs: the Natural Forest Protection Program (NFPP), which paid forest enterprises to stop logging natural forests and to increase the plantation area, and the Sloping Land Conversion Program (SLCP, also known as 'Grain for Green' and 'Returning Farmland to Forest'), which paid farmers to convert cropland on steep slopes to grassland or forest. Both schemes have had large impacts on forest cover [7], but the new forests are largely monoculture tree crops with few biodiversity benefits [2,8].

The outcome of the SLCP was heterogeneous, in part, as a result of the influence of local officials on the outcome of national policies [9]. These laws and policies are interpreted at a local level by county and village officials whose major objectives are improving the local economy and eradicating poverty. In our study area, Xishuangbanna in southwest China (Figure 1), these local priorities have resulted in the rapid replacement of much of China's most biodiverse native forests by rubber and tea monocultures [1]. Rubber occupied only 4.5\% of the total land area in 1999, mostly in state-owned plantations, but reached $24 \%$ in 2014 before declining slightly after the collapse of the rubber price. The area under tea, which is mostly grown in the frost-prone upland areas, also increased. In 2002, $71 \%$ of Xishuangbanna was covered in natural forest, but by 2018 this had been reduced to $52 \%$. However, under the SLCP, both rubber and tea count as 'forest', so there was officially no net forest loss. The state-owned natural forest area mostly survived, and much of this is now included in the Xishuangbanna National Nature Reserve and other protected areas, but a lot of both collectively managed forests and the forests assigned to households was cleared and converted to crops.

A new era in rural land-use policy started with the $13^{\text {th }}$ Five Year Plan (2016-020) and the development of the ecological redline policy [10]. Under this policy, all levels of government are required to designate and enforce ecological redline areas selected in order to maintain key ecological services: water conservation, flood mitigation, biodiversity conservation, soil conservation, and sandstorm protection. In contrast to earlier policies, environmental protection is now seen as the dominant role for forests and other natural and semi-natural ecosystems. The deadline for the completion of this task is the end of 2020 and Xishuangbanna is currently in the process of doing it. The redlined areas will include all the current protected areas, all other state-owned natural forests, all 'ecological public welfare forests' (natural collective forests with restricted uses), and a variety of additional forest areas. Xishuangbanna-which supports most of China's surviving wild Asian elephants-is also likely to be impacted by the creation of a new type of protected area for China, national parks, which will encompass multiple existing protected areas [11]. An Elephant National Park is currently under discussion. 


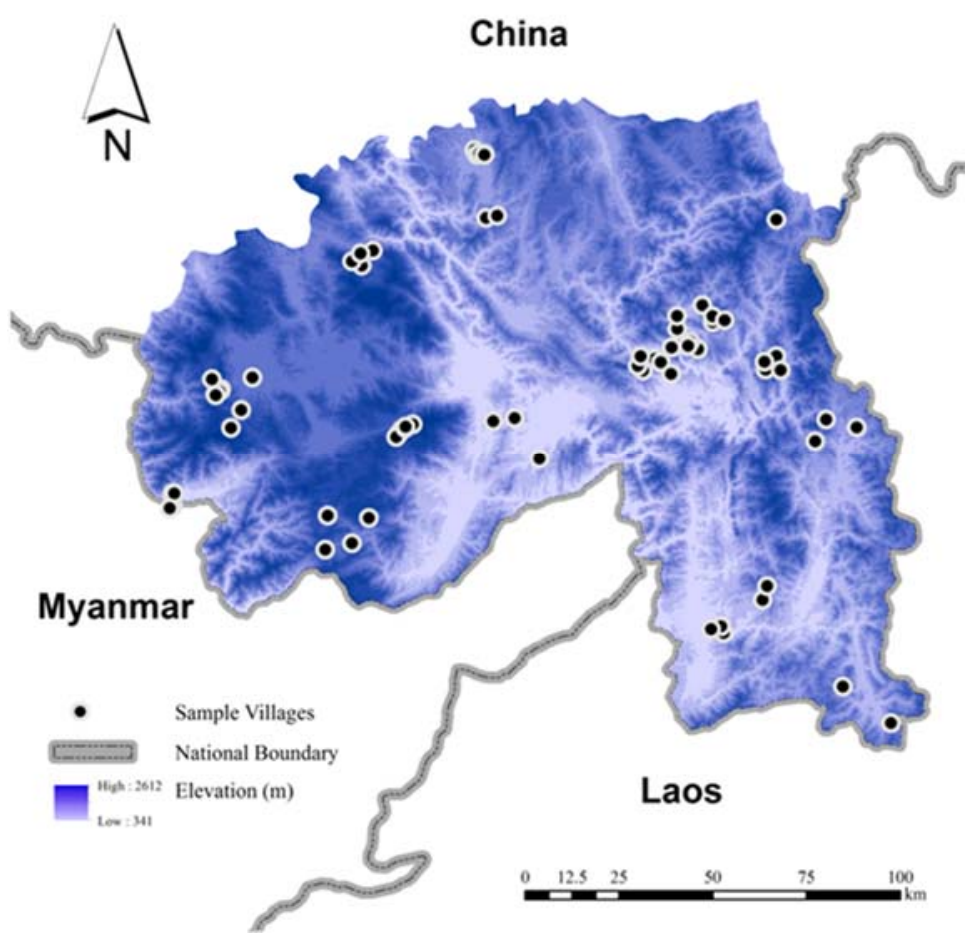

Figure 1. Locations of sampled villages in Xishuangbanna, southwest (SW) China.

Although all the largest forest patches in Xishuangbanna will now be protected by ecological redlines, thousands of smaller forest remnants of various shapes and sizes still persist on collective and household land. We will refer to all these forest patches as 'fragments', following the local and global literature [12], although a time series of remote-sensing images showed that they are a mixture of primary forest patches, disturbed to varying extents, and secondary regrowth of various ages [1]. There is no accessible land-tenure map of the prefecture, but interviews with a variety of stakeholders suggested that the largest remaining fragments (> 1000 ha) are all on state-owned land, the fragments of intermediate size are under collective or government tenure, and most of the smallest fragments $(<1 \mathrm{ha})$ are on land assigned to individual households [1]. Forest fragments $<100$ ha in area make up only $6.5 \%$ of the total forest area and have little value as breeding habitats for most vertebrates, but research in Xishuangbanna and elsewhere has shown their importance for conservation of plants and smaller animals $[12,13]$ and as stepping-stones for birds and mammals moving between larger fragments of forest [14]. They also sequester carbon, control erosion, protect water sources, and provide timber and non-timber forest products for local use $[15,16]$. Except in commercially deforested flatlands, such remnant fragments are a common feature of deforested landscapes across the tropics [17], but the reasons for their persistence have rarely been studied, except in the special case of forest patches protected for religious and cultural reasons [18].

These 'unofficial forests' in Xishuangbanna were the subject of this study. We used a combination of semi-structured interviews and key informants to attempt to answer three main questions: (1) Why were these natural forest fragments left, instead of being cleared for cash crops? (2) How do people use these fragments? (3) How do local people benefit from keeping these forest fragments? We then use the answers to these questions to discuss how government land-use policy and local practices can be aligned in order to preserve forest remnants throughout the agricultural landscape. 


\section{Materials and Methods}

\subsection{Study Area}

The Xishuangbanna Dai Autonomous Prefecture $\left(21^{\circ} 08^{\prime}-22^{\circ} 36^{\prime} \mathrm{N}, 99^{\circ} 56^{\prime}-101^{\circ} 50^{\prime} \mathrm{E}\right)$ is the southernmost political unit in Yunnan Province, southwest China, bordering Laos to the south and Myanmar to the southwest (Figure 1). The total area is $19,700 \mathrm{~km}^{2}$ and is characterized by mostly steep topography, with altitudes ranging from 341 to $2612 \mathrm{~m}$ above sea-level. The climate is monsoonal, with a hot wet season from June to October and a cooler dry season from November to May. With a total population of more than one million, Xishuangbanna includes 13 of China's 56 recognized ethnic groups: Han (China's major ethnic group and mostly urban here), Dai (the dominant minority), Hani, Yi, Lahu, Bulang, Jinuo, Yao, Miao, Bai, Hui, Wa, and Zhuang. In the absence of people, Xishuangbanna would be covered in evergreen and semi-evergreen tropical and tropical montane forests [19], but the valleys have been managed for centuries for intensive paddy-rice cultivation, smaller upland areas were used for tea production, and much of the rest was used for shifting cultivation of various forms. In the last 20 years, however, the expansion of cash crops, particularly rubber (Hevea brasiliensis Müll.Arg.) below $900 \mathrm{~m}$ above sea-level and tea (Camellia sinensis (L.) Kuntze) at higher altitudes, has replaced shifting cultivation and an increasing proportion of the forest, reducing the remaining forest to scattered fragments of various sizes [1,12]. Rubber occupied $4.5 \%$ of the total land area of Xishuangbanna in $1999,9.9 \%$ in 2002 , and $24 \%$ in 2014 , while forest cover declined from $71 \%$ to $52 \%$ over the same period [1]. A sharp decline in the rubber price since 2011 has halted and partly reversed the rubber expansion, but a natural forest is still being cleared for other crops, although at a slower rate.

\subsection{Interviews}

Field work was conducted from October 2016 to October 2017 using semi-structured interviews and key informant interviews. Both methods are widely used where a rigorous yet flexible data collection procedure is needed to collect qualitative data from people who are not used to talking about the subject of interest [20-23]. Villages for sampling (Figure 1, Table S1) were selected by generating 12 random $15 \times 15 \mathrm{~km}$ sample frames in the Create Fishnet tool in ArcGIS and then haphazardly choosing five villages within each frame. We excluded the intensively managed lowlands below $550 \mathrm{~m}$, where no forest survives outside protected areas. It is important to note that, although the sampled villages were mostly remote from urban areas, all villages in Xishuangbanna have road access, electricity, and water supplies, as well as reliable mobile phone and internet services, so interviewees were relatively well-informed of local, regional, and national issues. Within villages, we sampled households haphazardly by walking along major paths in the village. Semi-structured interviews were conducted in person with a self-chosen representative of each sampled household that had been allocated forestland. Thus, the villages were selected randomly and the households within them selected haphazardly, but we did not have a choice in who was interviewed from each household.

Key informants are people who have specialist insights into the research topic and are both willing and able to share their knowledge with the researcher [20]. Randomization was impractical, since we wanted to interview people with exceptional local knowledge, so a snowball method was used for recruitment, with participants in both interview groups suggesting possible recruits. This method of selection is clearly open to biases, so information from key informants was only used qualitatively.

Permission for this study was granted by Xishuangbanna Tropical Botanical Garden, Chinese Academy of Sciences. All interviews were conducted by the first author and an assistant, Xiaobing Lin. Interviews aimed to determine the reasons why natural forests fragments are retained instead of being replaced by cash crops, how local people use these fragments, and what benefits they obtain from keeping them. We first focused on forest fragments within their household's tenure (called "private forest" for simplicity) and then those under collective management by their village or group of villages ("collective forest"). Semi-structured interviews do not follow a formalized list of questions. Instead, the topics of interest are discussed by the interviewers and interviewees. The use of 
open-ended questions allows the participants to narrate the complexities of their lived experience, as well as allowing reciprocal interactions between the researcher and the interviewees [20,21]. Compared to questionnaire surveys, face-to-face interviews also enable the researcher to motivate respondents to participate and provide opportunities to evaluate the validity of the answers by observing non-verbal indicators [22].

In this study we faced a particular challenge in collecting standardized information as a result of the ethnic, cultural, and socioeconomic diversity of the participants. The first author belongs to a non-Han minority, has lived in the prefecture since 2013, and did fieldwork for her previous Master's project in Xishuangbanna, living in a Dai village. She therefore has a good understanding of local government structures and the economic pressures on smallholders. In order to gain trust and understand the local context, she usually arranged accommodation with a local family in the sample village and tried to participate in family activities, including agricultural work, housework, and festival ceremonies. We have no way of assessing the effectiveness of these factors in building trust, but they ensured that the interviewers were not mistaken for government officials and had enough local information to conduct effective interviews. Most villagers could communicate in either Mandarin or in the Yunnan dialect, which Xiaobing Lin could speak, but, if necessary, a local translator was hired and trained to help with interviews. The interviewers first explained who they were, what they were doing, and the objectives of the study. After consent was given, each interview lasted 90-120 minutes. Each interviewee was given a small gift after the interview to thank them for their participation, but they were not expecting any reward. Key-informant interviews were wider ranging and usually lasted 2-3 hours.

\subsection{Data Coding and Analysis}

A pilot study was first conducted in five villages in order to develop questions that could help elicit information efficiently, without encouraging particular answers or excluding unexpected findings. The information reported was categorized under three headings: Why was the forest retained? What was it used for? What were the benefits of retaining the forest? Within each category, a coding system for recording answers was developed based on the answers received during the pilot and additional possible answers based on the literature and our previous experience. Apart from the three research questions mentioned above, key-informant interviews also included additional topics related to forestland management, such as the main crops of the village, the water sources for local use, timber and non-timber product harvest from collective forests, wild animal conflict problems, cultural/religious beliefs, and others, depending on local context. The key-informant interviews complemented the semi-structured interviews by providing explanations for unexpected findings, and clarification and interpretation of the answers [23].

After the completion of the interviews, the primary field data that was related to the aims of the study was then categorized into natural groups, which were further subdivided as necessary. The reasons for retaining forest fragments were categorized as internal, external natural, and external social. Internal reasons derived from the owners' own plans and motivations; external natural reasons were natural conditions that made the fragment less suitable for clearance and cultivation; and external social reasons were government policies or other external social pressures in favor of retention. Uses of the fragments were categorized into daily life, agriculture, culture/religious beliefs, and others, while the perceived benefits were divided into utilization, for daily life or for profit, and environmental conservation. The Spearman's rank correlation was used to test the relationship between the percentage of households and the altitude of the village.

\section{Results}

A total of 609 households were haphazardly selected across 69 villages in 13 townships (the next higher administrative unit) in Mengla, Menghai, and Jinghong Counties, Xishuangbanna Prefecture (Figure 1, Table S1), among which only nine did not agree to be interviewed. The sampled households 
belonged to the Yi (24.7\%), Dai (19\%), Hani (18.7\%), Jinuo (13.5\%), Bulang (11\%), Lahu (7.1\%), Han $(5.5 \%)$, Bai $(0.3 \%)$, and Wa $(0.3 \%)$ ethnic groups, and were located between 578 and $1889 \mathrm{~m}$ above sea-level. Most (77.3\%) of the interviews were with male representatives of the household and only $22.7 \%$ with female. Ages of the interviewees ranged from 17 to 81, with $21.4 \%<35,42.5 \% 35-50$, $28.5 \%$ 50-65, and 7.6\% > 65. Formal education levels were none (12.4\%), primary school only (49.0\%), middle school (31.7\%), high school (3.7\%), secondary technical school (2.6\%), and junior college (0.7\%). The informal nature of the interviews and the open-ended questions resulted in considerable overlap between the answers to particular questions. The answers are reported separately here but should be interpreted together. The key-informant interviews were conducted with 16 people (14 male and 2 female), including Dai (6), Yi (4), Hani (2), Bulang (2), and Jinuo (2). The key informants were from different villages, with ages ranging from 34 to 55, and included 13 village leaders and 3 other village members.

\subsection{Reasons for the Existence of Natural Forest Fragments}

Most of the sampled households (63.7\%) retained private small fragments while $36.3 \%$ of them no longer did (Table S1). The percentage of households with fragments was strongly positively correlated with the altitude of the village (Spearman's rank correlation: $\rho=0.53, p<0.001$ ). A total of 16 reasons were collected from the interviews for the retention of natural forest fragments: 14 were mentioned (for a total of 711 times) for private forest fragments and 13 (1590 times) for collective forest (Table 1). Most (71\%) of the interviewees said that their fragment (or fragments, in some cases) were retained as a source of firewood, with most of these people also mentioning reasons why the site was not good for agriculture: poor soil (29\%), bad access (14\%), too many rocks (13\%), too steep (13\%), and/or too high altitude and thus too cold (7\%). Labor shortage (17\%) and enough cropland already (8\%) were the only other reasons given by many householders. Key informants from Padian (Bulang) and Manmabang (Hani) explained that, although natural gas ovens and gas cylinders were available, the frequency of the cylinder change service was too low. Also, firewood collection was inexpensive and convenient.

Table 1. Reasons for the retention of natural forest fragments. Percentages are the percentage of interviewees who gave this answer.

\begin{tabular}{|c|c|c|c|c|c|}
\hline \multirow{2}{*}{\multicolumn{2}{|c|}{ Category }} & \multirow{2}{*}{ Reason } & \multicolumn{2}{|c|}{ Percentage } & \multirow{2}{*}{ Explanation } \\
\hline & & & Private & Collective & \\
\hline \multirow{6}{*}{\multicolumn{2}{|c|}{ Internal }} & Cultural/religious & - & 96.26 & $\begin{array}{c}\text { Protected as holy hill, sacred grove or for other } \\
\text { cultural use. }\end{array}$ \\
\hline & & Fuelwood forest & 70.62 & 0.34 & Retained as a source of fuelwood. \\
\hline & & Labor shortage & 17.01 & 1.70 & $\begin{array}{l}\text { Household has insufficient people to clear and } \\
\text { cultivate site. }\end{array}$ \\
\hline & & Enough cropland & 8.25 & 5.78 & Household has enough cropland already. \\
\hline & & Pesticide impacts & 0.52 & 0.34 & $\begin{array}{c}\text { Crops would be impacted by pesticides from } \\
\text { surroundings. }\end{array}$ \\
\hline & & Low profits & 1.55 & - & $\begin{array}{l}\text { Expected profits do not justify clearance and } \\
\text { cultivation. }\end{array}$ \\
\hline \multirow{10}{*}{ External } & \multirow{4}{*}{ Natural } & Poor soil quality & 29.38 & 0.34 & Soil at the site too poor for any crop. \\
\hline & & Bad access & 14.43 & 2.04 & $\begin{array}{c}\text { Access to the site too poor for transporting } \\
\text { harvested crops. }\end{array}$ \\
\hline & & Too many rocks & 13.40 & 3.06 & The site has too many rocks to cultivate any crop. \\
\hline & & Too steep & 13.40 & 5.44 & $\begin{array}{c}\text { Slope of the site too steep to conduct } \\
\text { agriculture activities. }\end{array}$ \\
\hline & \multirow{6}{*}{ Social } & Too high altitude & 7.22 & 6.12 & The site is at too high altitude for cropping. \\
\hline & & Policy restriction & 3.09 & 100.00 & Clearance is forbidden by laws or policy restrictions. \\
\hline & & $\begin{array}{l}\text { Protect water } \\
\text { source }\end{array}$ & 1.03 & 25.51 & Retained to protect a water source for the community. \\
\hline & & Green belt & - & 16.33 & \multirow{3}{*}{$\begin{array}{c}\text { Retained as a 'green belt' for the village. } \\
\text { Retained until land allocation disputes are settled. } \\
\text { Adjacent to road construction site so difficult to } \\
\text { grow crops. }\end{array}$} \\
\hline & & Land disputes & 2.06 & - & \\
\hline & & Road construction & 1.03 & - & \\
\hline
\end{tabular}


In addition to private forest fragments, $92.8 \%$ of the sampled villages retained one or more areas of collective forest. Within the last 10 years, most of these had been designated 'ecological public welfare forests', in which uses are restricted in exchange for (rather small) compensation payments. All interviewees mentioned policy restrictions-i.e., some form of legal or administrative restriction on clearance-and most (96\%) mentioned cultural or religious reasons (Table 1). Key informants said that forests previously protected by the community for cultural or religious reasons were registered as collective forests during land allocation in order to guarantee continued community management. However, $87 \%$ of the respondents who reported the retention of forests as sacred groves (for cremating or burying the dead; Dai, Hani, Yi, Bulang) or holy hills (Dai) mentioned that the area had shrunk, particularly at low altitudes where the land was suitable for rubber or banana cultivation. The only additional reasons for collective forest retention mentioned by many householders were the protection of the village water supply (26\%) and acting as a green belt for the village (16\%).

\subsection{Uses of the Natural Forest Fragments}

Interviewees reported eight uses (556 times) for the private fragments and 12 (1758 times) for collective forests (Table 2). Most mentioned fuelwood collection (76\%) for private forest fragments and many also mentioned underplanting with crops (33\%). Most underplanting was with tea in villages where this was the major cash crop, but three respondents also mentioned Amomum villosum Lour. (Zingiberaceae, cultivated for its pods and seeds). Underplanting was never given as a reason for retaining the forest, suggesting that it was usually an opportunistic use of forest fragments retained for other reasons. The third most common use mentioned was as a forest fallow following shifting cultivation. Fragments also supplied construction timber (7\%) and wild edible plants (mainly mushrooms and bamboo shoots) (6\%). In Manzhang village (Daluo township), families had reached an agreement to rent out a large fragment, which had been parceled out among multiple households during land allocation to a tourism company in exchange for an annual share of the profits.

Table 2. Uses of the natural forest fragments. Percentages are the percentage of interviewees who gave this answer.

\begin{tabular}{|c|c|c|c|c|}
\hline \multirow{2}{*}{ Category } & \multirow{2}{*}{ Use } & \multicolumn{2}{|c|}{ Percentage } & \multirow{2}{*}{ Explanation } \\
\hline & & Private & Collective & \\
\hline \multirow{4}{*}{ Daily life } & Fuelwood & 76.29 & 43.88 & Used as a source of fuelwood. \\
\hline & $\begin{array}{l}\text { Wild edible plants } \\
\text { collection }\end{array}$ & 5.67 & 61.22 & $\begin{array}{l}\text { People collect wild edible plants } \\
\text { in the fragment. }\end{array}$ \\
\hline & $\begin{array}{l}\text { Construction } \\
\text { timber collection }\end{array}$ & 7.22 & 32.31 & $\begin{array}{c}\text { Timber cut to build new houses or } \\
\text { pigpens. }\end{array}$ \\
\hline & $\begin{array}{l}\text { Medicinal plants } \\
\text { collection }\end{array}$ & 0.52 & 0.68 & $\begin{array}{l}\text { People collect medicinal plants in } \\
\text { the fragment. }\end{array}$ \\
\hline \multirow{3}{*}{ Agriculture } & Under-cropping & 32.99 & 26.87 & $\begin{array}{l}\text { Crops (mostly tea) planted under } \\
\text { the forest canopy. }\end{array}$ \\
\hline & Fallow forest & 19.59 & - & $\begin{array}{c}\text { Fragment is secondary forest after } \\
\text { slash-and-burn. }\end{array}$ \\
\hline & Grazing cattle & 0.52 & 1.36 & Cattle feed in the fragment. \\
\hline \multirow[t]{2}{*}{$\begin{array}{l}\text { Culture/ } \\
\text { religious }\end{array}$} & $\begin{array}{l}\text { Burial or cremation } \\
\quad \text { for the dead }\end{array}$ & - & 95.92 & $\begin{array}{l}\text { Used as sacred grove and for } \\
\text { religious ceremonies }\end{array}$ \\
\hline & Wood for coffins & - & 15.65 & $\begin{array}{l}\text { Timber used to make coffins for } \\
\text { the dead. }\end{array}$ \\
\hline \multirow{3}{*}{ Other } & $\begin{array}{c}\text { Tourist attraction } \\
\text { management }\end{array}$ & 0.52 & 0.34 & $\begin{array}{l}\text { Rented to private company for } \\
\text { tourist attraction. }\end{array}$ \\
\hline & $\begin{array}{l}\text { Patrol for forest } \\
\text { safety }\end{array}$ & - & 1.02 & Rangers guard the forest. \\
\hline & Recreation & - & 1.02 & $\begin{array}{c}\text { People walk in the forest in their } \\
\text { leisure time. }\end{array}$ \\
\hline
\end{tabular}


Collective forest fragments had more uses. Cultural or religious use was mentioned most often (96\%), followed by the collection of wild edible plants (61\%), construction timber (32\%), understory crops $(27 \%)$, and the collection of timber for making coffins $(16 \%)$. Only tea was mentioned as an understory crop and key informants in tea villages explained that light shade increased tea quality, but trees would be girdled in dense forests to open up the canopy. Note that some villages had several collective forest patches, so not all these uses were necessarily carried out in the same patch, and that both legal and cultural restrictions on the use of collective forests varied among villages. It is also worth noting that, despite the level of trust established before the interviews, illegal uses of collective forests (such as uses forbidden under the rules agreed for ecological public welfare forests) may not have been reliably reported.

\subsection{Benefits of Keeping the Forest Fragments}

Interviewees mentioned nine benefits ( 238 times) for keeping private fragments and 13 benefits (935 times) for collective fragments (Table 3). Most benefits mentioned for private fragments related to daily use and increasing household incomes by improving soil fertility $(19 \%)$, raising income $(15 \%)$, providing back-up land for possible future use $(8 \%)$, improving tea quality $(7 \%)$, and supplying timber $(5 \%)$ and other forest products (4\%). A greater diversity of benefits was mentioned for collective forests, including a wide variety of practical uses, as well as the protection of the village environment (Table 3).

Table 3. Benefits of the existence of natural forest fragments. Percentages are the percentage of interviewees who gave this answer.

\begin{tabular}{|c|c|c|c|c|}
\hline \multirow{2}{*}{ Category } & \multirow{2}{*}{ Benefit } & \multicolumn{2}{|c|}{ Percentage } & \multirow{2}{*}{ Explanation } \\
\hline & & Private & Collective & \\
\hline \multirow{8}{*}{ Utilization } & Reserve land & 7.73 & 5.78 & $\begin{array}{l}\text { Future use when more profitable } \\
\text { crops available. }\end{array}$ \\
\hline & Timber stock & 4.64 & 8.50 & Possible future use of timber. \\
\hline & $\begin{array}{l}\text { Convenient for } \\
\text { daily use }\end{array}$ & 3.61 & 24.83 & $\begin{array}{l}\text { Convenient for daily collection of } \\
\text { forest products }\end{array}$ \\
\hline & $\begin{array}{l}\text { Potential tourist } \\
\text { attraction }\end{array}$ & 0.52 & 0.68 & $\begin{array}{l}\text { Potential for the village to establish a } \\
\text { tourist attraction. }\end{array}$ \\
\hline & $\begin{array}{l}\text { Improve soil } \\
\text { fertility }\end{array}$ & 19.07 & - & $\begin{array}{l}\text { Restoring soil fertility after use in } \\
\text { shifting cultivation. }\end{array}$ \\
\hline & Raise income & 14.95 & 7.48 & $\begin{array}{l}\text { More income by keeping and using } \\
\text { the fragment. }\end{array}$ \\
\hline & Improve tea quality & 7.22 & 6.12 & $\begin{array}{c}\text { Tea grows better under canopy shade } \\
\text { of the fragment. }\end{array}$ \\
\hline & $\begin{array}{l}\text { Government } \\
\text { subsidy }\end{array}$ & 2.06 & 18.71 & $\begin{array}{l}\text { Retention subsidized by the } \\
\text { government. }\end{array}$ \\
\hline \multirow{5}{*}{$\begin{array}{l}\text { Environmental } \\
\text { conservation }\end{array}$} & $\begin{array}{l}\text { Soil and water } \\
\text { conservation }\end{array}$ & 0.52 & 52.72 & $\begin{array}{l}\text { Fragment conserves soil stability and } \\
\text { a water source. }\end{array}$ \\
\hline & Windbreak & - & 13.61 & $\begin{array}{c}\text { Fragment shelters the village from } \\
\text { strong winds. }\end{array}$ \\
\hline & Purify the air & - & 9.18 & Fragment could help clear the air. \\
\hline & Climate regulation & - & 7.82 & $\begin{array}{c}\text { Fragment could help regulate the } \\
\text { village microclimate. }\end{array}$ \\
\hline & $\begin{array}{l}\text { Beautify the } \\
\text { environment }\end{array}$ & - & 3.40 & $\begin{array}{c}\text { Fragment helps to improve scenery in } \\
\text { the surroundings. }\end{array}$ \\
\hline
\end{tabular}

\section{Discussion}

The villages we sampled were extremely diverse, reflecting differences in their locations and physical environments, the ethnicities and cultures of the inhabitants, and the predominant crops, and the people we interviewed came from three different generations and a wide range of educational backgrounds. Despite this diversity, a relatively clear picture emerged from the interviews. Nearly two-thirds of interviewees had retained small forest fragments on the land assigned to their household, with the proportion retaining fragments increasing with village altitude. The fragments that were 
on land had low value for agriculture and were usually retained primarily as a source of firewood (Table 1), although they were then sometimes also used for other purposes (Table 2), particularly in tea villages where they were underplanted with tea. In many parts of the world, wood is the only fuel available or alternatives are too expensive for smallholders, but compressed gas and electricity are readily available in Xishuangbanna, and both tea and, until recently, rubber have provided reliable sources of cash income. Firewood, however, is cheaper and more convenient in villages remote from urban areas. Interviewees also perceived a wide range of other benefits of keeping forest fragments, although most of these were only mentioned by a few people each (Table 3). Despite the benefits of retaining forests, however, all interviewees had cleared most of their allocated land for growing crops and a third-mostly from lower altitude villages-had cleared it all.

More than $90 \%$ of the villages also had collective forests, the retention of which was always attributed to legal or administrative restrictions on clearance. Most collective forests were also of cultural or religious significance and had been protected for this reason before they were registered as collective forests. The beliefs and social structures which protected these sites in the past have weakened in recent decades, but they have not disappeared [18]. Despite the restrictions imposed by the public welfare forest policy, collective forests had a surprising number of practical uses, including extractive uses, and most interviewees also recognized their environmental values.

The central government's policy goals for China's forests have changed over the last four decades from an initial focus on producing a reliable supply of timber, to sustainable management, to, most recently, a focus on environmental protection. While these goals have been relatively easy to achieve in state-owned forests, this has been much more difficult with collectively owned forests, particularly when the use rights for these forests have been assigned to individual households. Despite a range of restrictions and incentives, our Xishuangbanna case study demonstrates that local factors have often dominated over national policies in decision-making on the ground. Government policies and environmental protection were rarely mentioned in relation to small fragments on private land, where land-use decisions were determined by trade-offs between the relative value of retaining the forest to the household and clearing it for crops. Non-allocated collective forests were perceived as very different, with policy restrictions always mentioned and environmental values recognized. However, it was usually the village's own choice to have the areas of forest previously retained for cultural and religious reasons recognized as a collective forest. Moreover, despite the joint protection of government policy and traditional beliefs, many of these forests have been reduced in size and degraded by the over-extraction of timber and other resources.

Enforcement of environmental rules and regulations has increased in recent years, and the implementation of the new ecological redline policy is intended to produce greater clarity about what is and is not allowed and to increase the effectiveness of enforcement [10]. Most of the larger forest areas in Xishuangbanna will be protected under this new policy, but it will not apply to small forest fragments on private land. In view of the potential value of these fragments as habitats for plants and small animals [1,12], as stepping stones for the movement of birds and mammals between larger forest patches [14], and for the provision of ecosystem services, new policies are needed to encourage their retention. Currently, their existence reflects a balance between the value of their continued use as forests and the value of the crops that could replace them. Until recently, the value of land for cash crops declined steeply with altitude. Profitable rubber cultivation requires frost-free sites with easy access for regular tapping, while the more cold-tolerant tea must be grown on one of the six traditional 'tea mountains' to receive a high price. However, new crops, like macadamia, mango, pomelo, and walnut, can be grown profitably at higher altitudes and only need access during the harvest season. The future of these fragments is therefore certainly not secure.

This conflict between agricultural intensification and nature conservation-and between government policies that support one or other of these-is by no means unique to Xishuangbanna and to China. Since 1992, reforms of the European Union's Common Agricultural Policy (CAP) have similarly attempted to reduce and, if possible, reverse the adverse impacts on biodiversity and 
ecosystem services resulting from the intensification that was previously encouraged [24]. Payments for these 'agri-environmental measures' now account for $7 \%$ of the entire CAP budget and are intended to compensate farmers for reduced income as a result of implementing them. In China, agri-environmental payments are also widely used, but most often to protect prime farmland from urban development [25]. A simple system of area-based payments for forest retention-perhaps with a premium for forest quality - might be enough to encourage forest conservation on private land in Xishuangbanna, and also in other regions of Yunnan facing similar issues.

\section{Conclusions}

Most households interviewed in this study retained small forest fragments on the land they had been allocated, although this was less common in the villages at lower altitudes, where more valuable crops, such as rubber, could be grown. These fragments were retained mainly as convenient sources of firewood but were also used for other purposes. Most villages also retained collective forests, most of which had previously been protected for cultural and religious reasons. These collective forests have multiple uses and clearly continue to play an important role in villages. National policies over recent decades have increasingly emphasized the environmental, rather than the economic, values of forests, but these policies have had relatively little impact on land-use in Xishuangbanna, where the loss of natural forests still continues. Smallholders make decisions largely on economic and practical grounds and, although the legal protection of collective forests has increased as traditional constraints on use have weakened, these forests have still suffered from a widespread reduction in area and continued degradation. The ecological red line policy promises to provide better protection in future for all the larger forest patches in Xishuangbanna, but some form of financial incentive will be needed to encourage the retention of small forest fragments on allocated land.

Supplementary Materials: The following is available online at http://www.mdpi.com/1999-4907/11/2/159/s1, Table S1: Sampled villages with name, major ethnic group, number of households, altitude, major crops, presence of collective forest(s), and proportion of households with forest fragments on their allocated land.

Author Contributions: Conceptualization, J.-Q.Z. and R.T.C.; methodology, J.-Q.Z. and R.T.C.; formal analysis, J.-Q.Z. and C.M.; writing-original draft preparation, J.-Q.Z. and R.T.C. writing-review and editing, all authors; supervision, R.T.C.; All authors have read and agreed to the published version of the manuscript.

Funding: This research was funded by the 1000 Talents Program (WQ20110491035).

Acknowledgments: We particularly want to acknowledge: at XTBG, Xiaobing Lin, for assistance with the interviews, and Jianwei Tang for help with local contacts, transport, and accommodation; at the Kunming Institute of Botany, Jianchu Xu and Deli Zhai for advice on fieldwork, and Huanfang Chen for help with sampling design and GIS; from the local government, Zhiyong Li, Song Lin, Zhongyou Li, En Yi, Feng Liu, and Yan Zhang, for explanations of government policies; and from the sampled villages, Xingrong Dong, Rongqiang Jiang, Dao Che, Wenli Han, Zaihun Ai, Zhuangxiang Yu, Bi Ai, Dacheng Jiang, Changming Li, Zonglei Chen, Xiaosi Long, Da Pa, Se Ai, Xuewen Dao, Yingla Ai, and Erba Luo, as well as all the other people who consented to interviews or helped in many other ways. Additional help was provided at critical times by Yupeng Liu, Kexuan Liu, Xiao Song, Liang Huang, Jianmai Gao, and Xiao Liang.

Conflicts of Interest: The authors declare no conflict of interest. The funders had no role in the design of the study; in the collection, analyses, or interpretation of data; in the writing of the manuscript, or in the decision to publish the results.

\section{References}

1. Zhang, J.-Q.; Corlett, R.T.; Zhai, D. After the rubber boom: Good news and bad news for biodiversity in Xishuangbanna, Yunnan, China. Reg. Environ. Chang. 2019, 19, 1713-1724. [CrossRef]

2. Zhai, D.-L.; Xu, J.-C.; Dai, Z.-C.; Cannon, C.H.; Grumbine, R.E. Increasing tree cover while losing diverse natural forests in tropical Hainan, China. Reg. Environ. Chang. 2014, 14, 611-621. [CrossRef]

3. Xu, Y.; Lin, S.; He, J.; Xin, Y.; Zhang, L.; Jiang, H.; Li, Y. Tropical birds are declining in the Hainan Island of China. Biol. Conserv. 2017, 210, 9-18. [CrossRef]

4. Liu, C.; Liu, H.; Wang, S. Has China's new round of collective forest reforms caused an increase in the use of productive forest inputs? Land Use Policy 2017, 64, 492-510. [CrossRef] 
5. Xu, X.; Tan, Y.; Yang, G.; Barnett, J. China's ambitious ecological red lines. Land Use Policy 2018, 79, 447-451. [CrossRef]

6. Yang, H. China's natural forest protection program: Progress and impacts. For. Chron. 2017, 93, $113-117$. [CrossRef]

7. Tong, X.; Brandt, M.; Yue, Y.; Horion, S.; Wang, K.; De Keersmaecker, W.; Tian, F.; Schurgers, G.; Xiao, X.; Luo, Y.; et al. Increased vegetation growth and carbon stock in China karst via ecological engineering. Nat. Sustain. 2018, 1, 44-50. [CrossRef]

8. Xu, J. China's new forests aren't as green as they seem. Nature 2011, 477, 371. [CrossRef] [PubMed]

9. Zenda, J.A.; Zhang, Z. Explaining heterogeneous afforestation outcomes: How community officials and households mediate tree cover change in China. World Dev. 2019, 122, 385-398. [CrossRef]

10. Jiang, B.; Bai, Y.; Wong, C.P.; Xu, X.; Alatalo, J.M. China's ecological civilization program-Implementing ecological redline policy. Land Use Policy 2019, 81, 111-114. [CrossRef]

11. Xu, W.; Pimm, S.L.; Du, A.; Su, Y.; Fan, X.; An, L.; Liu, J.; Ouyang, Z. Transforming protected area management in China. Trends Ecol. Evol. 2019, 9, 762-766. [CrossRef] [PubMed]

12. Liu, J.-J.; Slik, J.F. Forest fragment spatial distribution matters for tropical tree conservation. Biol. Conserv. 2014, 171, 99-106. [CrossRef]

13. Volenec, Z.M.; Dobson, A.P. Conservation value of small reserves. Conserv. Biol. 2019. [CrossRef] [PubMed]

14. Zhang, M.; Chang, C.; Quan, R. Natural forest at landscape scale is most important for bird conservation in rubber plantation. Biol. Conserv. 2017, 210, 243-252. [CrossRef]

15. Hu, H.; Liu, W.; Cao, M. Impact of land use and land cover changes on ecosystem services in Menglun, Xishuangbanna, Southwest China. Environ. Monit. Assess. 2008, 146, 147-156. [CrossRef]

16. Liu, S.; Yin, Y.; Liu, X.; Cheng, F.; Yang, J.; Li, J.; Dong, S.; Zhu, A. Ecosystem services and landscape change associated with plantation expansion in a tropical forest region of Southwest China. Ecol. Model. 2017, 353, 129-138. [CrossRef]

17. Tulloch, A.I.T.; Barnes, M.D.; Ringma, J.; Fuller, R.A.; Watson, J.E.M. Understanding the importance of small patches of habitat for conservation. J. Appl. Ecol. 2016, 53, 418-429. [CrossRef]

18. Zeng, L.; Reuse, G. Holy hills: Sanctuaries of biodiversity in Xishuangbanna, southwest China. In Asian Sacred Natural Sites; Verschuuren, B., Furuta, N., Eds.; Routledge: Abingdon, UK, 2016; pp. 204-216. [CrossRef]

19. Zhu, H.; Cao, M.; Hu, H. Geological history, flora, and vegetation of Xishuangbanna, southern Yunnan, China. Biotropica 2016, 38, 310-317. [CrossRef]

20. Bernard, H.R. Research Methods in Anthropology: Qualitative and Quantitative Approaches, 5th ed.; AltaMira Press: Lanham, MD, USA, 2011.

21. Galletta, A.; Cross, W.E., Jr. Mastering the semi-structured interview and beyond: From research design to analysis and publication. Thorax 2013, 13, 222-228.

22. Barriball, K.L.; While, A. Collecting data using a semi-structured interview: A discussion paper. J. Adv. Nurs. 1994, 19, 328-335. [CrossRef]

23. Newing, H. Conducting Research in Conservation: A Social Science Perspective; Routledge: Abingdon, UK, 2010.

24. Früh-Müller, A.; Bach, M.; Breuer, L.; Hotes, S.; Koellner, T.; Krippes, C.; Wolters, V. The use of agri-environmental measures to address environmental pressures in Germany: Spatial mismatches and options for improvement. Land Use Policy 2019, 84, 347-362. [CrossRef]

25. Zhu, L.; Zhang, C.; Cai, Y. Varieties of agri-environmental schemes in China: A quantitative assessment. Land Use Policy 2018, 71, 505-517. [CrossRef]

(C) 2020 by the authors. Licensee MDPI, Basel, Switzerland. This article is an open access article distributed under the terms and conditions of the Creative Commons Attribution (CC BY) license (http://creativecommons.org/licenses/by/4.0/). 